\title{
Decentralisatie revisited
}

\author{
Roel in 't Veld'
}

35 jaar geleden schreef ik in dit tijdschrift een artikel over decentralisatie onder de titel 'Decentralisatie van onder af bezien' (1979, 123-134). Daarin constateerde ik dat er geen uitgewerkte decentralisatietheorie beschikbaar was. Het artikel behelsde een poging om vanuit bestuurskundige optiek verstandig over decentralisatie te spreken en niet alleen te verwijlen bij de juridische concentratie op overdracht van bevoegdheden.

Sedertdien ontwikkelde ik de notie van sturingsnetwerk waarin de decentralisatiegraad van besluitvorming, aangrijpingspunten voor sturing en bestuurlijk instrumentarium in onderling verband zijn geordend. Veel andere bestuurskundigen concentreerden zich op netwerktheorie. We weten nu dat bevoegdheden en invloed niet een-op-een met elkaar corresponderen, dat dominantie en afhankelijkheid - begrippen die ik toen ook hanteerde - niet alleen multidimensionaal zijn, maar ook een interne specifieke dynamiek vertonen, en dat reflexiviteit alle sturingspretenties sterk relativeert.

Decentralisatie is inmiddels een versleten begrip. Alles wat zich weg van een centrum beweegt, is als decentralisatie getypeerd. De taalkundige vormgeving duidt op een proces. Willen we de toestand beschrijven, dan spreken we over decentraal of gedecentraliseerd. Voorgenomen decentralisaties in het sociale domein houden ons bezig. Hier wil ik graag aandacht schenken aan het ontwerp van een adequaat begrippenapparaat om zinvol over dit type van decentralisatie te spreken.

Wat is dit type van decentralisatie? Zichtbaar is het voornemen tot overheveling van aanzienlijke budgetten nadat daarop is gekort. Begeleidende wetgeving regelt de overgang naar een meer decentrale bevoegdhedenstructuur. Aan de operatie ligt een aantal overwegingen ten grondslag:

- Een meer geïntegreerde behandeling van cliënten/patiënten kan tot kwaliteitsverhoging en tot doelmatigheidsvergroting leiden.

- De gemeente heeft een beter zicht op de cliënt/patiënt dan het Rijk.

- Een meer gevarieerde aanpak van casuïstiek op grond van specifieke omstandigheden in een bepaald gebied is gewenst.

- De voorkeuren van een lokale bevolking met betrekking tot zorg aan eigen medeburgers zijn relevanter dan rijksvoorkeuren, en daarom dienen lokale voorkeuren te domineren.

- De gemeente is geschikter om de zelfredzaamheid van burgers te stimuleren.

- De gemeente kan doeltreffender toezicht houden op uitvoering.

De geloofwaardigheid van elk van deze overwegingen hangt in sterke mate af van de bril die men opzet. De politieke dialoog is gedomineerd door aansprekende schrikverhalen over multi-probleemgezinnen die struikelen over de hulpverleners

* Prof. dr. Roel in 't Veld is hoogleraar bestuurskunde aan de Universiteit van Tilburg. E-mail: roelintveld@hotmail.com. 
met onderling tegenstrijdige aanbevelingen. Maar het uitleggen van de fysieke nabijheid van de gemeente als superieur waarnemingsvermogen is natuurlijk deels te betwisten. De Belastingdienst bijvoorbeeld, kent de financiële omstandigheden van inwoners echt beter dan de gemeente. Waarnemen vergt competenties die niet oneindig deelbaar zijn; daarom bestaat er een voortdurend vraagstuk aangaande het arrangeren van schaalverschillen.

In veel beschikbare teksten dwarrelen deze overwegingen door elkaar heen. Uiteraard ontstaan bij realisatie spanningen met criteria als (rechts)gelijkheid en rechtszekerheid, die gelden voor een nationale samenleving als geheel. Deze politieke afweging moet allereerst op het centrale niveau plaatsvinden: welke bandbreedte van verschillen acht het Rijk aanvaardbaar? De parlementaire discussie hierover heeft geen helderheid gebracht. In het debat over de Jeugdwet op 9 oktober 2013 bijvoorbeeld, is sprake van een wens naar nationale outcome-indicatoren! Gevraagd naar zo'n indicator antwoordt een van de woordvoerders vanuit de coalitiebanken: 'Daar gaat de outcome aan hangen dat kinderen op een liefdevolle manier worden opgevangen in een gezin.' Er dient zich een klein meetprobleem aan, zou ik zeggen, en bovendien lijkt mij hier van een outcome geen sprake. De invloed van toezichthouders komt in voornoemd debat nauwelijks ter sprake. Veelzeggend is de ophef die ontstond toen een wethouder in Deventer aanstalten maakte om inderdaad enig specifiek beleid te gaan voeren. De staatssecretaris was er als de kippen bij om de geest weer in de fles te krijgen. Wellicht is het vermoeden gewettigd dat vaagheid over de aard en omvang van de decentrale ruimte enerzijds onontkoombaar is omdat er geen spoor van consensus hieromtrent is te vinden, en anderzijds een gezaghebbende uitlating omtrent de daadwerkelijk toe te kennen ruimte de weerstand vanuit de gemeenten tegen de hele operatie snel zou laten stijgen. Een schitterende toepassing dus van politics of ambiguity.

Veelal is een tweetal kenmerken van de situatie waarin zorgverlening plaatsvindt, verwaarloosd:

- De meeste professionals die in het sociale domein zorg verlenen, zijn niet ondergeschikt aan een overheid en opereren in een krachtenveld dat slechts ten dele is te beïnvloeden door territoriale overheden.

- De organisaties waaraan veel professionals zijn verbonden, hebben een groot aantal externe bindingen, waaronder die met verzekeraars en toezichthouders, naast eventuele contractuele banden met één of meer gemeenten.

Als we op de werkelijke situatie inzoomen, valt op dat in veel specialisaties de professionaliteit zich sterk heeft ontwikkeld in de richting van standaardisatie van het werk door protocollering. De argumentatie ten gunste hiervan luidt dat op deze wijze best practices algemeen goed worden, en dat zo de kwaliteit van de beroepsuitoefening toeneemt. Toezicht richt zich dan ook in aanzienlijke mate op de vraag of het protocol is gevolgd. Dit betekent dat in de alledaagse situatie samenwerkende professionals uit verschillende disciplines in het algemeen niet over de ruimte beschikken om een Neue Kombination te ontwikkelen. Naarmate dit stringenter het geval is, kan er dus in een bepaald geval wel assemblage van bepaalde bestaande praktijken plaatsvinden, maar blijven verantwoordelijkheden gescheiden en is geen op de casus toegespitste integratie van de inhoud van zorg 
mogelijk. Een aanzienlijk deel van de betrokken organisaties en professionals is ook qua financiering niet afhankelijk van de gemeente, maar van verzekeraars en/of consumenten. Kortom, de onderlinge relaties van alle betrokken instanties zijn veelsoortig, en de gemeente is daarin vaak niet de krachtigste partner en in een aantal gevallen tot op heden zelfs in het geheel geen partner.

Indien het ambitieniveau van een gemeente zich uitstrekt tot werkelijk geïntegreerde zorgverlening door professionals uit verschillende disciplines, zal er een beschermde ruimte moeten bestaan voor leerervaringen en experimenten waartoe de afzonderlijke toezichthouders geen toegang hebben, zodat zij afwijkingen van protocollen ook niet kunnen sanctioneren. Het is niet eenvoudig daarvan de karakteristieken te beschrijven. Ontwikkelen zich specifieke praktijken, dan zal de toezichthouder niet langer kunnen volstaan met uniforme kwaliteitsmaatstaven, omdat de eigen waardeoriëntatie van de gemeente zal doorklinken in wat is ontwikkeld en er dus ook een specifiek kwaliteitsbegrip zal gelden. In dit licht is het voornemen voor uniforme landelijke prestatie-indicatoren tamelijk omineus.

Binnen de kennisdemocratie waarin wij leven zijn veel specifieke uitingen van verstrengeling van media en politiek en van wetenschap en politiek waar te nemen, die in elk beleidsdomein aparte gedaanten aannemen: in het medische complex anders dan in het binnenlands bestuur (In 't Veld, 2010a, 2010b, 2013a, 2013b; In 't Veld \& Van Daal, 2013). Gemeenschappelijk is de hype, als cumulatie van mediapolitieke en niet zelden ook mediawetenschappelijke interactie een fenomeen dat vaak kentering inluidt: uit de scandaleuze casus ontwikkelt zich een algemene beleidswijziging. Bij de onderhavige decentralisaties botsen zeer uiteenlopende beleidstheorieën op elkaar. De disciplinaire opdelingen in de wetenschap en professies over het brede sociale domein verhinderen ook de totstandkoming van consensus omtrent een gemeenschappelijke beleidstheorie, waarvan een gemeenschappelijk gezichtspunt op decentralisatie deel zou kunnen uitmaken. In de door dit kabinet gesloten akkoorden zijn die botsingen bij vergelijking ook glashelder. In belendende domeinen zoals onderwijs leidt de hype meestal tot (re)centralisatie. Het is mij op voorhand niet duidelijk waarom dit hier niet zou gelden. Zo is de (hoogstens vergulde) kooi geconstrueerd: decentralisatie is alleen dan zinvol indien variëteit kan toenemen, maar als de variëteit toeneemt, zal een onwelgevallige praktijk snel tot recentralisatie leiden, die vervolgens de variëteit in het algemeen dwangmatig laat dalen.

In de voorgaande alinea's is ervan uitgegaan dat decentralisatie in elk geval ruimte moet creëren voor de honorering van lokale politieke voorkeuren omtrent voorzieningenniveau en bejegening. Dit zou toch moeten betekenen dat het bestuur van een gemeente ten minste ten dele definieert waarop burgers mogen rekenen, in aanvulling op de voor volksverzekeringen op nationaal niveau bepaalde polis. Vervolgens zal de gemeente er zorg voor dragen dat de toegezegde voorzieningen ook daadwerkelijk tot stand komen, en daartoe haar eigen organisatie inzetten in samenwerking met een groot aantal op enigerlei wijze verbonden partijen. De aard van deze binding kan sterk uiteenlopen, evenals de discretionaire ruimte die voor de uitvoerder aanwezig is.

Voor het verplaatsen van werk zonder discretionaire ruimte naar een andere overheid gebruiken we andere termen, zoals deconcentratie of gebonden mede- 
bewind. Maar is de operatie ook legitiem indien het daarop neer zou komen? In de begripsvorming binnen het domein is veelal sprake van ketens: geschakelde reeksen van op elkaar afgestemde activiteiten die bestuurd worden door netwerken, groepen van semiautonome actoren die zich bewust zijn van complementariteit en voldoende empathie ontwikkelen ten behoeve van effectiviteit. Wie herinnert zich niet de Suwi-keten? Een netwerk heeft geen baas nodig, wel procesarchitectuur.

Uit keten- en netwerktheorie is ook bekend dat de decentrale netwerken groot gevaar lopen indien de afzonderlijke actoren naast hun netwerkbinding ook andere sterke bindingen kennen, omdat dan het gevaar voor double binds en daarmee voor schizoïde ontwikkelingen ontstaat. Wie het sociale domein overziet, struikelt over gevaren van deze aard. Ex ante analyses over onbedoelde effecten zijn dan ook broodnodig. In de transitietheorie is een krachtige aanbeveling geformuleerd voor dit type ontwikkelingen, te weten de oproep tot reflexieve monitoring (Grin, Rotmans \& Schot, 2010). De gemeente is niet de meest reflexieve bestuurslaag die wij kennen, maar het volgen van voornoemde aanbeveling zou hier wel eens lijfsbehoud kunnen zijn.

Voor de gemeentelijke organisatie houden de decentralisaties een belangrijke uitdaging in. Het verbinden van uitkeringen, zorg en arbeidsmarktbeleid vergt over een breed front eensluidend optreden met een intensiteit die het Rijk nooit waar heeft kunnen maken. Bovendien zijn ook belendende percelen zoals de verstrekking van urgentieverklaringen voor woonruimte in het geding. Zodoende is het coördinerend vermogen wel een cruciale variabele, terwijl voorts de organisatie van onderaf wordt aangesproken vanuit wijkteams of een overeenkomstig construct, en regels vaak niet helpen om in een specifieke casus adequaat op te treden. Dus opnieuw spanning, ditmaal tussen de op bestuurlijk niveau vastgestelde randvoorwaarden en de behoefte aan specifieke benadering van afzonderlijke casussen.

De complexiteit die de onderhavige decentralisaties oproepen, uit zich dus in spanningen tussen professionele standaarden en protocollering tegenover de behoefte om professionele competenties te herschikken in geïntegreerde nieuwe zorgverlening, in de verhouding tussen bestuurlijke besluitvorming en ruimte ter wille van een adequate benadering van casussen - ongelijke behandeling van ongelijke gevallen -, en in de verhouding tussen algemene beginselen als rechtsgelijkheid en rechtszekerheid en de behoefte aan variëteit in de uitvoering.

Op basis van de plausibele veronderstelling dat deels afhankelijke actoren zich in hun feitelijk gedrag zullen laten leiden door de meest gezaghebbende actor, kan men zich zorgen maken over de uitkomst van kwesties waarin de gemeente zorgverleners aanspoort tot ander gedrag dan de toezichthouders of nationale principalen in het algemeen wenselijk achten. Vorenstaande analyse van krachtenvelden verschaft een meer realistisch perspectief op de vermoedelijke uitkomsten van de komende decentralisaties dan een geloofsovertuiging alleen. 


\section{Literatuur}

Grin, J., Rotmans, J., \& Schot, J. (2010). Transitions to Sustainable Development. New York: Routledge.

Veld, R.J. in 't (1979). Decentralisatie van onder af bezien. Beleid en Maatschappij, 6 (5-6), 123-134.

Veld, R.J. in 't (2010a). Kennisdemocratie, opkomend stormtij. Den Haag: Sdu.

Veld, R.J. in 't (Ed.) (2010b). Knowledge Democracy, Consequences for Science, Politics and Media. Heidelberg, Springer.

Veld, R.J. in 't (2013a). Macht en verantwoordelijkheid in de kennisdemocratie. Christen Democratische Verkenningen, 3: 92-102.

Veld, R.J. in 't (2013b). De Rob als producent van politieke utopie. Bestuurskunde, 3: 88-95.

Veld, R.J. in 't, \& Daal, R.A.J.H. van (2013). Overheid in transitie. Openbaar Bestuur, 2:

7-11. 